Article

\title{
A Systematic Review of Eco-Innovation and Performance from the Resource-Based and Stakeholder Perspectives
}

\author{
Russell Tatenda Munodawafa $₫$ and Satirenjit Kaur Johl * \\ Department of Management and Humanities, Universiti Teknologi PETRONAS, 32610 Seri Iskandar, Perak, \\ Malaysia; russell_17003483@utp.edu.my \\ * Correspondence: satire@utp.edu.my; Tel.: +60-5-368-7756
}

Received: 7 August 2019; Accepted: 17 September 2019; Published: 1 November 2019

check for updates

\begin{abstract}
The growing concerns surrounding the precarious state of the biosphere have triggered organizations to develop and implement innovations that curb environmental degradation (eco-innovation). However, eco-innovation is a risky proposition for organizations and their stakeholders, due to uncertainty of outcome. Despite the high investment risk of eco-innovation, the literature that assesses eco-innovation outcomes from an organizational performance perspective is scant. Thus, this paper uses a systematic approach to review eco-innovation and performance literature. The eco-innovation and performance literature reviewed in this paper is sourced from the Scopus and Web of Science (WoS) scientific databases. Results from this systematic review suggest that the capital market stakeholder group — an essential stakeholder group-has received little attention in the eco-innovation and performance literature. This is alarming, as this stakeholder group is expected to act in the best interests of the organization-as well as the other stakeholders-especially during strategy formulation and implementation. This paper also finds that the resource-based view and stakeholder theory are frequently utilized in explaining eco-innovation. However, the natural resource-based view is least utilized, despite growing environmental pressures. A multi-theoretical perspective can help to overcome the limitations of one theory, as well as help to unearth additional organizational factors which could potentially catalyze the eco-innovation and performance relationship.
\end{abstract}

Keywords: eco-innovation; cleaner production; strategy; performance; natural resource-based view; stakeholder theory

\section{Introduction}

Growing concerns about the state of the natural environment are mainly centered upon waste management, greenhouse gas (GHG) emissions, pollution and contamination management, natural resource management, as well as food, water and energy security [1]. The rising prominence of these natural environmental challenges has trigged global and local policy adjustments, as well as industry initiatives to stymie these challenges. Examples of such initiatives includes the establishment of 17 Sustainable Development Goals (SDGs) by the United Nations (UN) in 2015. These 17 SDG goals are a global attempt, led by the United Nations, to direct the world towards sustainable development [2]. The SDGs, which incorporate approximately 169 targets under the "Transforming our world: The 2030 Agenda for Sustainable Development" manifesto, are largely based upon the recommendations of the Brundtland Commission of 1987 [3]. In this report, experts and scientists acknowledged the negative effects that anthropogenic activities were theoretically having on the biosphere [4].

According to the report, corrective action needs to be taken if humanity is to avert an imminent natural environmental crisis. Remedial and preventive action will help ensure the continuous, 
uninhibited operation of the biosphere, which serves the dual functions of resource provider and anthropogenic emissions sink [5]. Thus, development needs to be sustainable; i.e., it needs to focus on satisfying present needs without negatively impacting future generations' ability to satisfy their own needs [6]. As a result, environmental sustainability, one of the three pillars of sustainable development, has become the nexus for international agencies, governments, academics and industry practitioners worldwide [7]. Further driving attention towards sustainable development is the growth of the consumer consciousness of environmental sustainability issues [8], as well as a stricter enforcement of environmental regulations [9]. Hence, to meet the targets of sustainable development, industrial activities should be undertaken within the threshold of the natural environment, vis-à-vis sustainable development.

For industry to usher in sustainable development, organizations need to shift from focusing solely upon profit. Instead, organizations must continue their pursuit of profit without neglecting the interests of planet and people, as the protection of the biosphere will influence current and future competitiveness for organizations [10]. Environmental challenges are thus a potential boon for organizations to increase their competitiveness and performance. This is because the increasing prominence of environmental issues enables organizations to integrate environmental initiatives (eco-initiatives) into their strategy. These eco-initiatives require the engagement of all stakeholder groups to reap the benefits [11]. In turn, the organization's problem-solving capability vis-à-vis environmental innovativeness is improved [12]. In fact, organizations that channel their resources and capabilities towards addressing environmental challenges will realize greater competitive advantages [13]. For instance, firms that embed waste and GHG emission minimization into their ethos by practicing continuous improvements of their products can develop the strategic capability of pollution prevention. This capability could potentially foster lower production costs [13]. Therefore, for organizations to improve on their environmental innovativeness, they must direct their resources towards eco-innovation [12].

Eco-innovation is defined as innovation which encompasses the development of new ideas, technologies, behaviors, products, or processes that result in the reduction of environmental burdens whilst simultaneously improving economic performance [14]. Also included in this definition of eco-innovation are organizational changes - where stakeholders (groups or individuals, whose actions affect the organization and vice-versa [15]) are the key elements [16].

In addition, improving environmental sustainability through reducing the usage of non-renewable resources, and minimizing hazardous waste generation, could possibly lead to a permanently regenerative economy [17]. Consequently, eco-innovation's emphasis on the environment also makes it an ideal catalyst in the transition from a linear economy to a closed loop, circular systems of production and consumption-i.e., the "circular economy" (CE). This capability makes eco-innovation more distinct from other types of innovation [18]. For example, applications of eco-innovations, such as micro fuel cells for combined heat and power production, enables buildings to lower their $\mathrm{CO}_{2}$ and other GHG emissions [19]. Thus, capabilities exhibited by eco-innovations enhance sustainable development mainly through: Reducing non-renewable resource dependence, materials and energy consumption, as well as waste and hazardous materials production [20,21].

Eco-innovation is not just the domain of one industry. It is applicable across multiple industries within the wide expanse of the consumption and production system [22]. Hence, a multidisciplinary approach is paramount towards addressing issues related to the environment, economy and society at large. Because of its technological nature [23], eco-innovation has been addressed in a number of engineering-oriented studies [24]. However, eco-innovation needs to be receiving attention from a strategic perspective as well, due to its potential to renew business models and inspire value creation activities [25]. Eco-innovation can also be viewed from non-technological angles, such as institutional and organizational contexts, i.e., its governance and management [26]. Anzola-Román et al. [27] posit that the non-technological activities of an organization can also be a meaningful source of innovation.

When looked at as a process, the output (eco-innovation) can be attributed to its strategy, routines and resources [27]. These aspects are all a function of the various stakeholders of the 
organization [28]. Hence, having a firmer understanding of eco-innovation and its role in the transition to sustainable development will help influencers in the eco-innovation process-such as the stakeholders of the organization-to better adjust and calibrate their organization's resources and capabilities towards better performance [18].

Eco-innovation is also a risky proposition for organizations. This is due to the uncertain outcome and impact of any type of innovation, including eco-innovation [29]. Consequently, the linkage between an organization and its stakeholders is critical in minimizing the risks associated with the uncertainty of eco-innovation [30]. Organizations should make eco-innovation the main focal point of their strategic planning, so as to possibly minimize their risk, and also to enhance their strategic and economic performance [31].

Despite these assertations, studies that analyze eco-innovation from a strategic perspective are scant. Specifically, the mapping of organizational strategic factors to eco-innovation (such as resources, capabilities and stakeholder groups, e.g., top management), remains obscure [32]. This is alarming, given that strategic organizational systems can benefit from eco-innovation. Also concurring with this point is Tyl et al. [33], who stated that eco-innovation literature ought to capture how different stakeholders understand and interpret the challenges to the natural environment. Literature that captures the stakeholders' insight into the environmental concept would help to effectively gauge the environmental value proposition for an organization's stakeholders [33].

In addition, eco-innovation literature that calls into focus organization-level determinants and drivers is currently limited. The 'bottom line' or non-technical contextual outcomes of eco-innovation literature, such as performance, have received limited coverage [34]. Also, organizational structural factors play a fundamental role in shaping the eco-innovation capabilities of organizations. However, studies discussing these eco-innovations seem to overlook the role of key stakeholder groups, such as the top management and shareholders. Yet, these stakeholders have a direct bearing on the internal eco-innovative capabilities of the organization, as they influence the culture and structural aspects of such organizations [35]. In fact, a critical gap was pointed out by He, Miao, Wong and Lee [26], who found that most eco-innovation literature that assesses its theory development is mostly skewed towards technical outcomes. As a result, the existing literature fails to explicitly account for internal and external factors, such as capabilities and stakeholders, that account for the competitive performance outcomes of eco-innovation [26]. In addition, theory usage in eco-innovation literature has predominantly focused on the resource-side of the value creation process. As a result, demand-side perspectives-where other stakeholders are present and can potentially influence eco-innovation value creation eco-system - has been largely neglected. Hence, paying attention to contextual factors such as market dynamics, together with the stakeholder groups behind them, can help in further understanding eco-innovation and performance [26]. Knowing the performance outcomes of eco-innovations is essential, given the high financial risk involved in eco-innovations [36]. Thus, this paper aims to address this current gap in literature by looking at the role of the organizational and contextual factors towards eco-innovation, and subsequently, performance. By addressing this gap, potential, resource, capability and stakeholder factors that can be mapped to the eco-innovation and performance relationship, can be unearthed, providing the opportunity to suggest future eco-innovation and performance research directions.

Therefore, this paper seeks to answer the following research questions:

1. What are the current organizational and contextual factors that influence the eco-innovation and performance literature?

2. What are the key organizational and contextual factors that can potentially be mapped to the eco-innovation and performance relationship?

3. What are the possible future research avenues for eco-innovation and performance literature? 
The remainder of this paper is structured as follows: Section 2 presents the background and theoretical development of eco-innovation. Section 3 describes the methods used in this paper. Section 4 presents the findings, whilst Section 5 discusses the findings. Lastly, Section 6 concludes the paper.

\section{Background}

Innovation as a concept was first brought to prominence in the 1930s by Joseph Aloïs Schumpeter, who saw innovation as the industrial or commercial application of new business models, production methods, processes, products, or even supply source to strategically encourage economic development [37]. The initial interpretation of innovation during this era related it to changes of varying magnitudes (i.e. small or large scale) that significantly amplify holistic changes in entire industries or market segments. This indicates that, by definition, innovation is connected to change. Innovation, however, should not only be restricted to change abstractly. Newness or novelty must also be present. Thus, the element of novelty (newness) in applications (industrial or commercial) demarcates innovation from invention, even if the entity behind both the innovation and invention are the same [37].

Innovation is, hence, a function of value creation, and subsequently competitive advantage [38]. This viewpoint on innovation is also supported by Kotsemir, Abroskin and Meissner [29], who stated that innovation encapsulates changes, whose aim is to create value. This value addition should positively impact the performance of the organization on numerous fronts, such as operational efficiency, improved working practices, or better flexibility in an ever-changing business environment. Hence, innovation is a source of competitive advantage, through it being a capability [39-41]. As a capability, innovation is arrived at through utilizing organizational resources, which conjures sustainable competitive advantage [42].

Innovation also encompasses other facets which include, but not solely, technical development [43]. Other aspects about innovation include marketing, financing, strategic planning and stakeholder engagements, such as governments and supply chains [44,45]. This fact highlights the cross-cutting, multifaceted nature of innovation.

Innovation definitions, however, have traditionally viewed it from a product perspective-i.e., making innovation synonymous with new products. There are, however, other dimensions to innovation such as strategy, process or value-adding service innovations-which represent a new, generally overlooked frontier [29,46,47]. These innovation dimensions-which are a function of an organization's resources-represent an organization's innovativeness or innovation capability when they are aggregated [48-50].

Integrating environmental initiatives into an organization's strategy has convincingly demonstrated its ability to buttress an organization's innovativeness and competitiveness [51]. Hence, environmental innovativeness is another important frontier, as environmental issues become increasingly prominent $[52,53]$. As organizations become more pro-active in addressing environmental concerns, environmental innovativeness becomes an increasingly important capability $[54,55]$. This is because environmental innovativeness presents organizations state-of-the-art problem solving vis-à-vis the implementation of eco-initiatives [12]. These eco-initiatives—which require the engagement of all stakeholders at all levels-can assist in creating a competitive advantage through several means, such as cost reduction [11,56] or environmental compliance [57].

Furthermore, when environmental initiatives are integrated into novel commercial or industrial applications, economic development can thus be stimulated without causing irreversible harm to the natural environment [58]. Green, McMeekin and Irwin [58] were amongst the early scholars to point out the increasing need of incorporating the natural environment into novel applications. As a result, the term eco-innovation was formulated and introduced by Rennings [14]. Eco-innovation was thus defined as encompassing the development of new ideas, technologies, behaviors, products, or processes that result in a reduction of environmental burdens, whilst concurrently improving economic performance [14]. 
Although Rennings [14] was one of the first to coin the term eco-innovation, several attempts to define this innovation have been made by various scholars and government bodies. For instance, the European Commission's definition of eco-innovation placed more emphasis on the environmental performance (positive or negative) of innovations, instead of simply focusing on the aim of the eco-innovation [59]. Meanwhile the Organization for Economic Co-operation and Development (OECD) defined eco-innovation as: "The production, assimilation or exploitation of a product, production process, service or management or business method that is novel to the organization (developing or adopting it) and which results, throughout its life cycle, in a reduction of environmental risk, pollution and other negative impacts of resources use (including energy use) compared to relevant alternatives." [60].

Managing resources, economies, and the environment, in a responsible manner, without harming the prospects of future generations, is critical. Corporations, consumers, policy makers and researchers play a leading role in reducing the degradation to the natural environment and ensuring sustainable development [61]. Because these stakeholders are the engines for economic development and growth, this paper adopts the OECD's definition of eco-innovation. Carrillo-Hermosilla et al. [62] also support this definition of eco-innovation, since they argue that economic stimulation through the reduction of any negative environmental impact should be the distinguishing hallmark of eco-innovation from other innovation. Hence, eco-innovation seeks to positively influence both environmental and economic performance simultaneously through means such as cost reduction and improved efficiency.

Eco-innovation and its impact on performance has been studied by various scholars who encompass a wide spectrum of theoretical backgrounds. As a result, several theories on eco-innovation have been postulated by various scholars within areas such as Finance, Economics, Law \& Strategic Management [63], Engineering [64], Urban Planning [65] and Environmental Science [66]. However, Pham, Paillé and Halilem [12] argued that environmental innovativeness is the blueprint to eco-innovation. Therefore, from a theoretical perspective, eco-innovation is a competency that can be arrived at from utilizing resources. This helps to explain why research on eco-innovation and performance has largely been studied from the resource-based view [67].

The definition of eco-innovation, as posited earlier, is inclusive of organizational changes, and according to Carrillo-Hermosilla, del González and Könnölä [16], the stakeholders are key in organizational factors. In fact, there have been increasing calls for the integration of stakeholder viewpoints into eco-innovation [24,33]. For instance, Bag and Gupta [68] indicate that further research should attempt to integrate the resource-based view with other theories, especially in observing eco-innovation. Therefore, the theories applied in this study include the resource-based view and the stakeholder theory.

One of the basic building blocks of an organization are its resources and/or capabilities [69]. An organizational resource is loosely defined as being anything that could be classified as a strength of the organization, and are key to its success [70]. Creating the conditions for the optimum usage of an organization's resources could possibly help to generate higher returns of time [70]. Whereas, capabilities factor in the ability of an organization to effectively and efficiently utilize its resources [71].

From the perspective of an organization, products/services and resources are closely related, as most products/services require the utilization of several resources, and most resources can be inputs to several products/services. In order for an organization to reconfigure and realign its competencies and resources towards accomplishing eco-innovation - and in turn-better performance, its various stakeholders play a fundamental role in this process [72]. Therefore, looking at the resource profile of an organization can be useful in helping it fine tune its product-market activities.

The resource-based view postulates that a competitive advantage can be built and sustained from the strategic harnessing of an organization's resources [73,74]. An organization is able to coordinate and cross-functionally integrate the exploitation of its resources to develop a competency. 
The degree to which an organization attains a competitive advantage, and therefore higher performance, is determined by the value $(\mathrm{V})$, rareness $(\mathrm{R})$, imitability $(\mathrm{I})$ and Organization $(\mathrm{O})$ of its competencies [74-76]. In addition, a resource-based view of strategy-a function of stakeholders such as top management who formulate strategy in conjunction with the organization's ownership-helps to further optimize the resource utilization of organizations. Efficient and effective exploitation of an organization's valuable, rare resources and capabilities can help establish a competitive advantage. This in turn can lead to higher performance, benefiting the organization's ownership [77,78].

\section{Materials and Methods}

Building an exceptional literature review requires a methodical and systematic approach. Hence, the use of a systematic approach towards the literature review, i.e., the systematic literature review-is highly recommended by scholars due to its rigorous, formal and scientific nature [79]. Utilizing a systematic literature review procedure is beneficial to research from the management and organizational domain, as it enables researchers to deduce context-sensitive research logically and reliably, improving the overall output [80]. Therefore, this paper conducted a systematic review of the available literature, using the 3-stage principles and procedures formulated by Tranfield et al. [81] to answer the research questions. These three main stages consisted of planning, execution and reporting. This procedure, which commenced on the 4 February, and finalized on the 3 May 2019, was selected as it has been geared towards research in the management domain.

As part of the planning stage, a review protocol was established. The protocol would guide the literature review process through defining the review parameters. The first condition for the studies to be included is that they must be investigating eco-innovation and performance as the main concept. This inclusion condition was put in place for several reasons. Firstly, to ensure that the literature remains within the focused scope of this paper. Secondly, to ensure that the paper does not deviate away from the main domain of the focal research. Thirdly, eco-innovation as a concept is transdisciplinary, covering a wide expanse of technologies, practices and services. Hence, numerous synonyms have been used in conjunction with eco-innovation [82]. Consequently, semi-independent and autonomous sub-fields will emerge, which may result in the researchers deviating away from the scope of the research [81]. Lastly, focusing on studies that investigate eco-innovation and performance as the main concept will help to answer the research questions. Hence, focusing exclusively on studies that investigate eco-innovation ensures the paper remains within the bounds of the research scope. Only empirical research papers were included, as they featured empirical results of investigations on eco-innovation. Therefore, review articles, books and book chapters where excluded.

Eco-innovation is a research area that has yet to mature-with scholarly research publications beginning around the year 2000 [83]. The second inclusion criteria, therefore, specifically focuses on research that falls between the years 2000 and 2018. In addition, this paper also excluded records that were not available in English.

Following the definition of review parameters, the steps to be followed during execution and reporting were established. These steps which assisted the paper in compiling the publications for further analysis are described in the framework illustrated by Figure 1. 


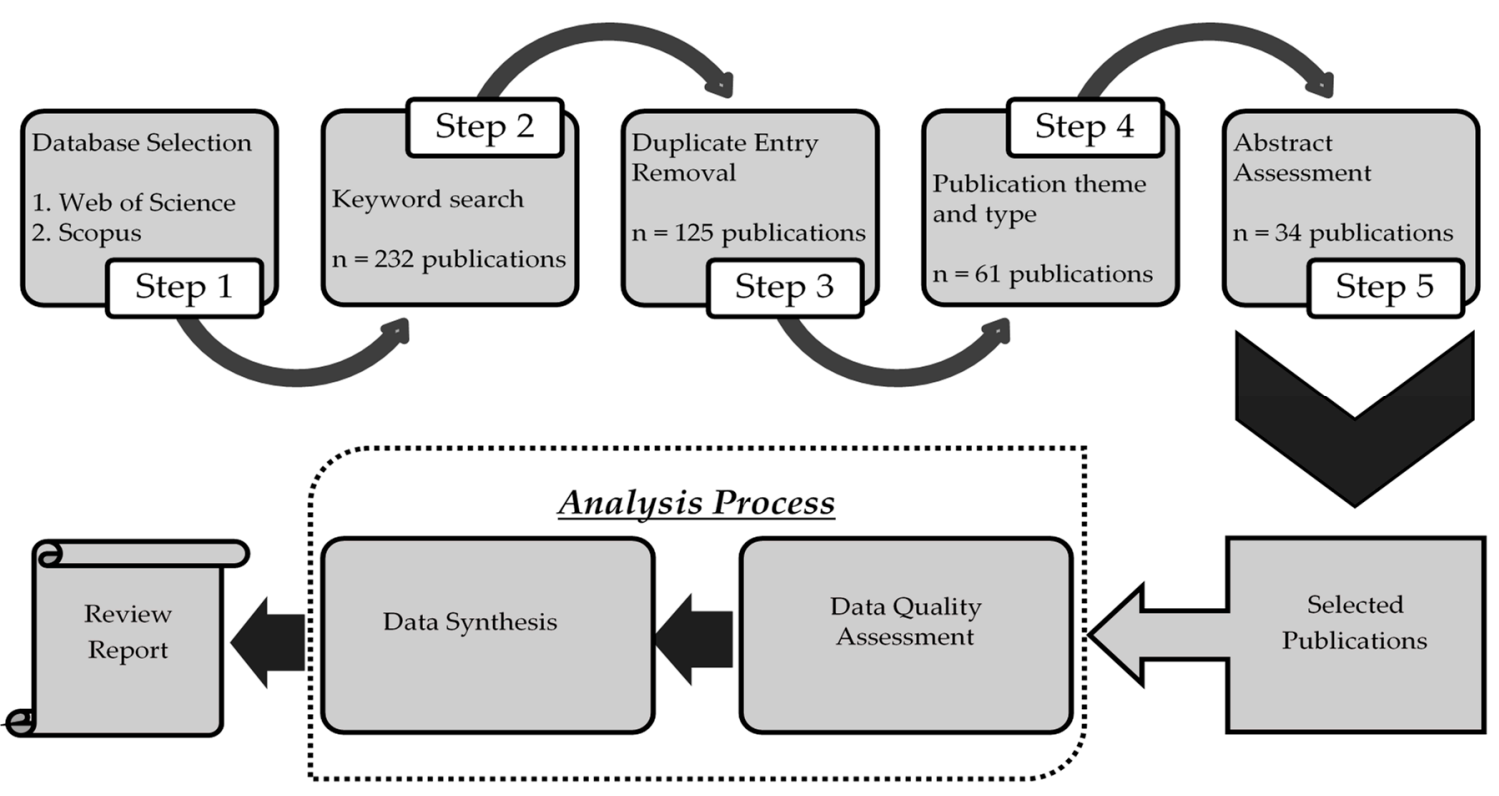

Figure 1. Illustration of the Review Process (Authors' own elaboration).

\subsection{Step 1: Database Selection}

This paper undertook its information search from two major scientific databases of knowledge, Scopus and the Web of Science (WoS). This paper utilized these two databases, as they are accessible to the researchers via the institution's information center subscription. As a result, the researchers can access top tier publications from the likes of Science Direct, Emerald, Wiley and Springer. Furthermore, these two scholarly databases are the current leading research publication institutions where current, up to date journal publications can be sourced [84]. Hence, utilizing these databases affords this paper access to abundant sources of knowledge within the scope of this paper, as these databases feature top tier publications [85].

\subsection{Step 2: Keyword Search}

The keywords to be utilized in this paper were in line with answering the research questions. Hence, the strategy for searching the databases for articles needed the usage of the AND operator. The AND operation would be utilized in searching for research articles that follow the concepts laid out in the inclusion and exclusion criteria. The performance word was utilized so as to include other precursor synonyms to refer to an organization such as firm or corporate.

Following the search location and strategy, Table 1 summarizes the keywords that were utilized in the search databases:

Table 1. Keyword Search.

\begin{tabular}{ccccc}
\hline Theory & Search String & Scopus & WoS & Total \\
\hline Resource-based & Eco-innovation AND Performance AND resource-based & 40 & 62 & 102 \\
Stakeholder & Eco-innovation AND Performance AND stakeholder & 85 & 45 & 130 \\
\hline
\end{tabular}

\subsection{Step 3: Duplicate Entry Removal}

After combining the search results from the two databases, the results returned a total of 232 records as of 31 December 2018. The publication results were then compiled to create a full list of the publication records. Thereafter, the search string results were validated by removing duplicate publication records from the Scopus and WoS Databases. This was a necessary step, given the preceding step of combining publication records from both databases into the one list. Hence, some duplicate publication records were expected to be seen-as some publication records are available on both Scopus and WoS. EndNote 
Version $\mathrm{X} 8$ was used to facilitate this process. After removing duplicate publication records from the search string results, 125 publication records remained.

\subsection{Step 4: Publication Theme and Type}

Next, the inclusion and exclusion criteria were then applied to the remaining 125 search results. Articles need to be empirically analyzing eco-innovation and performance for final inclusion in this paper. After the application of inclusion and exclusion criteria, a total of 61 papers where then selected to undergo an examination of the title and abstract, to make sure that the records are in the field of eco-innovation and performance.

\subsection{Step 5: Abstract Assessment}

At this stage, an abstract analysis was conducted on the remaining 61 papers. Only papers that fulfilled the inclusion criteria as specified in the review protocol where selected. Studies whose abstract did not, or was not, in the context of eco-innovation and performance, were not selected. Therefore, in total, 34 papers from the 61 where then selected for final in-depth qualitative synthesis. This resulted in 34 publication records being selected to undergo further qualitative synthesis, helping the paper remain within its scope.

\subsection{Step 6: Analysis Process}

An assessment of the quality of the selected articles was then undertaken prior to data synthesis. This was carried out in order to provide a picture on the relevance and recency of the selected studies and their impact. Journal Impact Factor and CiteScore $® q u a r t i l e ~ r a n k i n g$, as well as citations, are a proxy indicator of the quality of study, as studies accepted into these publications have undergone rigorous research quality assessment [86].

Next, after quality assessment, the selected articles were synthesized in order to gather the data from the articles. Main ideas were analyzed, and their effect, i.e. eco-innovation and its impact on performance through content analysis. Once data was extracted and synthesized, this paper then discussed the findings. Gaps identified were also discussed, and recommendations for possibly addressing the gaps where then presented.

\section{Results}

\subsection{Data Quality Assessment}

Most of the selected studies in this paper came from journal sources that are ranked in the top Quartile according to Scopus's CiteScoreßranking system in their respective fields. Journal of Cleaner Production, Business, Strategy and the Environment, as well as Sustainability-which are also top ranked journals-are some of the source titles for a number of the selected studies. The source title for one of the studies is not covered under Scopus's CiteScore®system. Instead, it is ranked in the Web of Science's Emerging Sources Citation Index (ESCI).

Despite the concept of eco-innovation being established in the year 2000, its connection to performance did not gain much attention in the first 10 years post 2000. There were limited attempts to connect eco-innovation to performance from a strategic and stakeholder perspective, with the notable attempts being made post 2010. Only from the year 2016 did the publication numbers for eco-innovation and performance literature begin to gain traction. Hence, most of the analyzed publications are quite recent; i.e., within the last three years, as eco-innovation and performance research is yet to mature.

\subsection{Data Synthesis}

Stakeholders play a critical role in an organization's performance. Because of the influence of their actions and the influence of the organization's actions on them, their synergy is pivotal to key areas of the organization such as performance. And one of the key organizational aspects that is inextricably 
linked to performance is strategy [87]. The strategy, which determines the bearing of an organization, is often the culmination of stakeholders' synergy. The performance of an organization is not just critical for its own success. It is also of interest to the numerous stakeholders. Hence, the bearing of an organization's strategic direction is a function of the various stakeholders, as the organization relies on them for its performance. The stakeholders in return are also reliant on the organization's performance [88].

Stakeholders can be classified according to their various abilities to wield influence; namely primary (e.g., owners, suppliers, employees); secondary (e.g., government, pressure groups); and outside (e.g., market forces, societal trends) [89].

However, the stakeholder groups have recently been reclassified according to major groups; namely: Capital market stakeholders (e.g., shareholders, suppliers of capital); product market stakeholders (e.g., customers, suppliers, host communities); and organizational stakeholders (e.g., employees, managers, non-managers) [90].

The capital market stakeholder group — consisting of shareholders (institutional or individual)—is one of the most important stakeholder group, as they assume the risk and provide to finance the firm, and expect to generate a return on their risk and financial investment. This group also has the ability to influence the firm through a number of means, such as selecting and appointing the executives/top management (principals) to run the organization [90]. In addition, these executives are pivotal in strategy formulation [91]. Meanwhile, product market and organizational stakeholders, such as employees, suppliers and managers buttress strategy implementation [92], highlighting the important functions of stakeholders for organizations. Figure 2 illustrates the distribution of literature focusing on the role of stakeholder groups in the eco-innovation and performance literature. As can be witnessed, a large percentage of eco-innovation and performance literature has been dedicated to the product market and organizational groups, yet only a fraction has focused on the capital market stakeholder group.

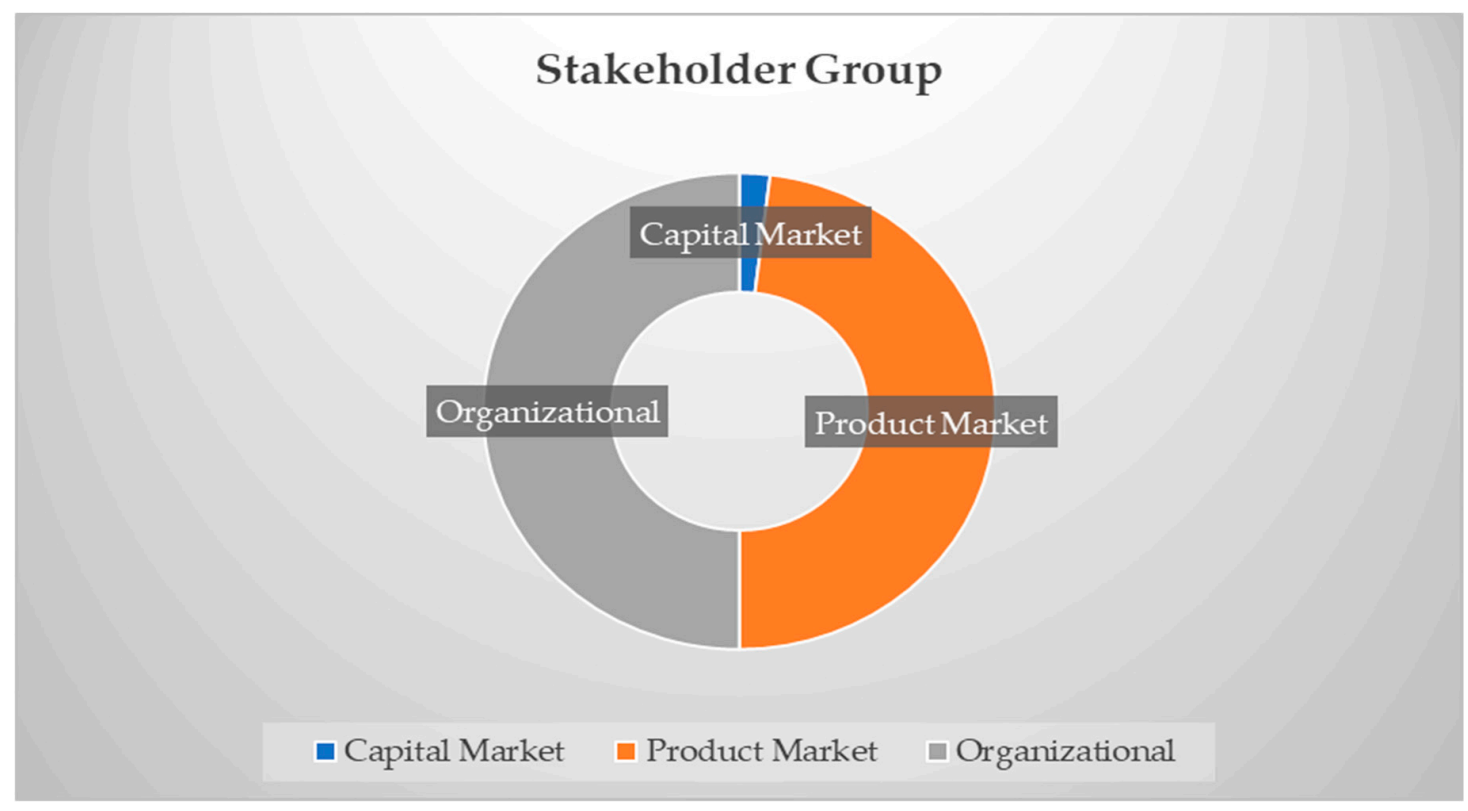

Figure 2. Eco-innovation and Performance: Stakeholder groups.

Furthermore, one of the keys to achieving excellent organizational performance through sustainable value creation is to align strategy and eco-innovation [93]. In order to align its strategy and eco-innovation, an organization needs to consider its resources and capabilities (the ability for an organization to efficiently and effectively utilize its resources) [70]. 
Effective and efficient utilization of valuable, rare and inimitable organizational resources can enable an organization to develop capabilities that optimize its product-market activities. Optimization of product-market activities, in turn, help an organization's performance through a competitive advantage [74]. Resources thus enable organizations to develop unique innovations vis-à-vis their capabilities. Therefore, resources and capabilities are indispensable to the strategy, innovativeness and performance of organizations [94].

Thus, in terms of resources, capabilities and stakeholders, eco-innovation and performance research has mostly focused on identifying various sets of drivers. These drivers themselves emanate from the various stakeholders interacting with the organization, as highlighted in Figure 3.

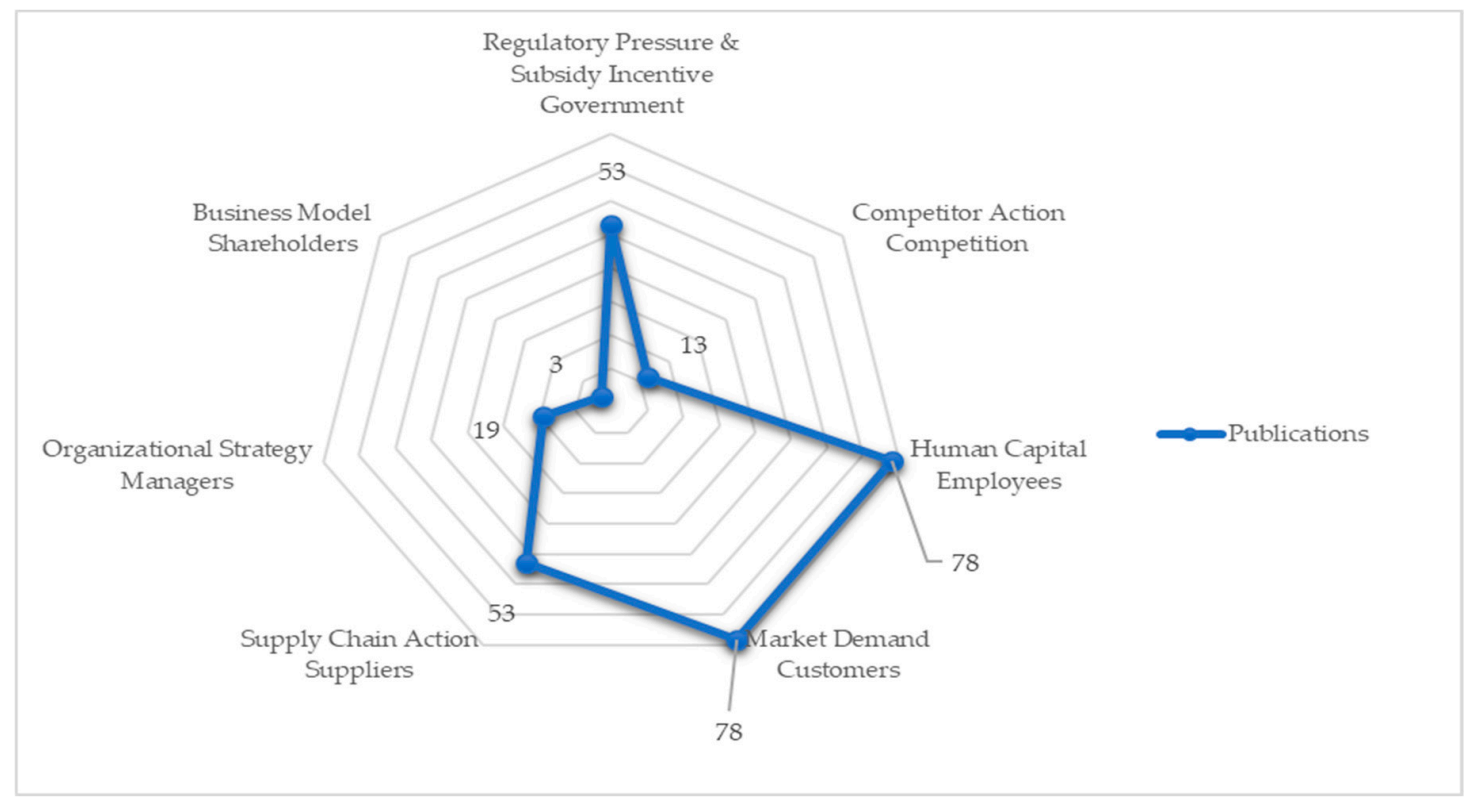

Figure 3. Eco-innovation and Performance: Drivers and Stakeholders.

Figure 3 also presents an illustration of the identified drivers and the stakeholder factor behind the driver. The identified driver behind each factor has been grouped into their respective stakeholder group (see Figure 2). Most literature identified human capital, market demand, supply chain requirements and regulations as key drivers for the eco-innovation and performance relationship. Meanwhile, organizational strategy, competitors and the business model were also pointed out as drivers, but did not receive as much attention as the other drivers. However, the publications highlighting the capital market stakeholder group are few. Only a handful of studies have paid attention to this group's influence towards the eco-innovation and performance relationship.

Furthermore, the selected publications were also assessed from an industry perspective, as highlighted by Figure 4. Even though eco-innovation and performance literature has been growing post 2010, there seems to be a disproportionate focus of literature, with much of it derived from manufacturing.

A high proportion of the selected publication has focused on the manufacturing industry. Less than 10 percent of studies emanated from the services sector, indicating a coverage that is heavily skewed towards the manufacturing sector. 


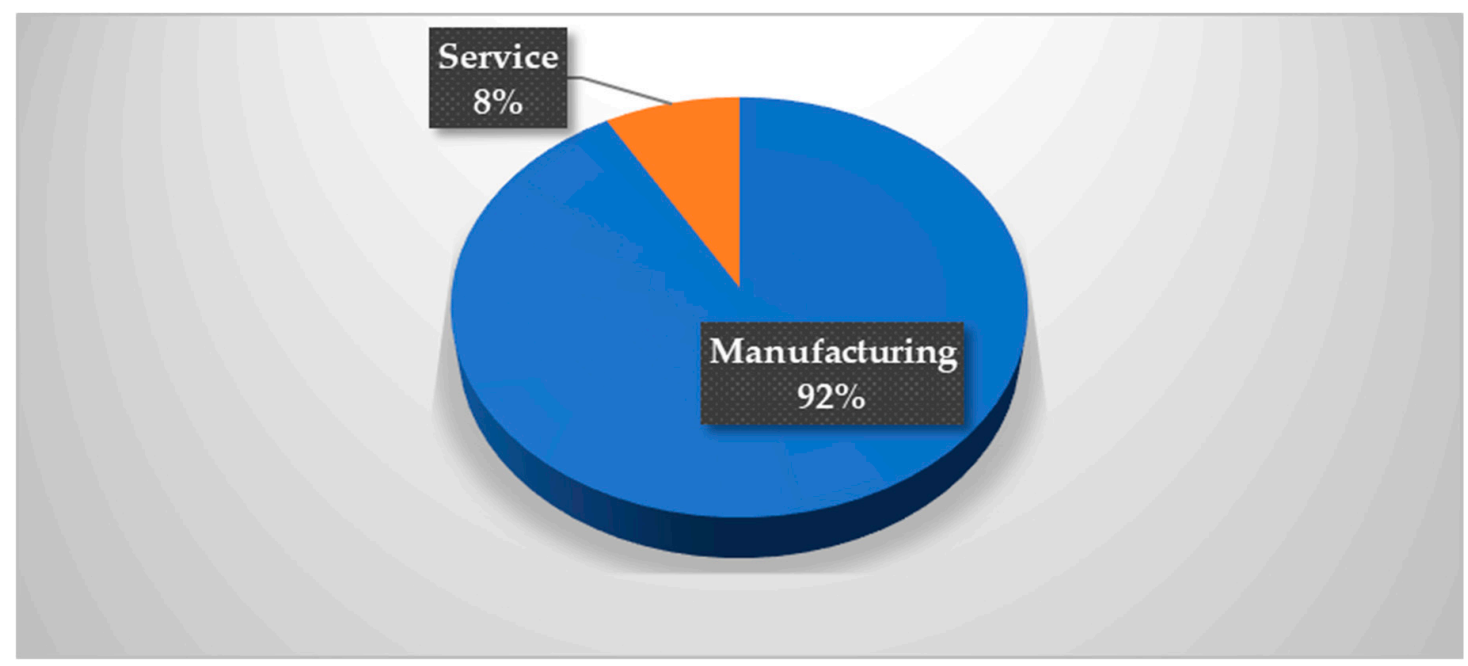

Figure 4. Industry Coverage of Eco-innovation and Performance.

\subsubsection{Eco-innovation and Performance: Regulatory Effects}

Environment regulations have been a prominent driver in the adoption of eco-innovation by organizations. Environmental policies formulated by governments, especially those that seek to curb waste generation, environmental pollution and GHG emissions, would require organizations to comply in order to operate-regardless of their size $[95,96]$. Regulation has been found to be a strong antecedent to eco-innovation [97]. In fact, meeting regulatory standards has proven to cause a threefold increase in the likelihood of organizations engaging in eco-innovation [98], underscoring the importance of environmental policy formulation, enforcement and monitoring by the authorities, as also suggested by Fernando, Wah and Shaharudin [95]. Hence, when organizations eco-innovate to make their market offerings comply with environmental regulations, they derive better performance overall as a result of compliance with set environmental regulations. Furthermore, potential revenue streams are created as a result of environmental compliance [99]. Perhaps this may also be unique in cases where regulatory authorities incentivized environmental compliance [100-102]. In addition to the potential revenue streams that are created, compliance with environmental regulation was also found to boost an organization's environmental performance [103].

One of the ways that can help an organization to improve or comply on environmental regulation is by engaging in dialog with stakeholders [104,105]. A possible reason why stakeholder engagement is important emanates from the earlier findings of Blum-Kusterer and Hussain [106], Galliano et al. [107] and Ratten [108], who all agreed that apart from regulation, pressure from the various stakeholders can influence organizations to adopt eco-innovation or increase their eco-innovation practices. An example of this is illustrated by the findings of Bossle et al. [109], who stated that it is not only government that pressures organizations to eco-innovate so as comply with regulation. In fact, it was noted by other researchers that government played a minute role in making organizations eco-innovate [109]. Pressure to eco-innovate came from the other stakeholders (competitors, customers and suppliers). As a result of normative pressures from this group of stakeholders, organizations that do not eco-innovate find themselves not being able to compete in the market, hence the need to eco-innovate. Tsai and Liao [110] concur with this argument, when they also found that it was the lure of revenue and performance, rather than regulations, that enticed organizations to eco-innovate, underlining the importance of the product market stakeholders.

\subsubsection{Eco-innovation and Performance: Market Dynamics}

The lure of potential revenue and performance is, in fact proving to be the underlying reason for organizations eco-innovating. This is due to the mixed results of regulation as a driver for eco-innovation [109-111]. In fact, the growing consumer awareness of environmental issues is creating 
a distinct set of consumers who engage in sustainable consumption and are willing to pay premium pricing to products that are eco-friendly [112]. Hence, it is the allure of financial performance through increased turnover from eco-products. An example is illustrated by the growing consumption of eco-products, as well as other value propositions created through the utilization of eco-processes and cleaner production technologies [112-114]. Interestingly however, other studies found that eco-innovation did not contribute to performance [104,114].

\subsubsection{Eco-innovation and Performance: Organizational Factors}

It is not just the market as well that increases the propensity of organizations eco-innovating. Employees are also increasingly playing a pivotal in organizations' eco-innovative capabilities, thus contributing to performance. For instance, it was argued that employees have a major role to play in the outcomes of eco-innovation and the performance of organizations [115].

This could be due to employees being important sources of knowledge, and therefore being a critical resource and stakeholder $[99,114]$. In fact, managers are also an important key in the eco-innovation and performance chain $[111,116,117]$. In fact, it was pointed out that environmental concern by the management of an organization buttressed eco-innovation-subsequently contributing positively towards performance [118]. This viewpoint is further corroborated by the argument that increased managerial concerns for the environment directly increased the performance of organizations which eco-innovate [109].

\section{Discussion}

This section presents the discussion points and gaps identified from the systematic review of the literature.

\subsection{Eco-innovation and Performance: Drivers}

The literature identifies and discusses drivers of eco-innovation. These drivers are important, as they play a key role in eco-innovation adoption - with performance then derived from eco-innovation. However, whilst drivers of eco-innovation and their impact on performance are subsequently covered and discussed by the literature, the majority of the factors are derived from the product market and organizational stakeholder group. Hence, most research analyzing the eco-innovation and performance relationship looks at the influence that stakeholders who come from the product market and organizational groups impose on the relationship. However, studies that mentioned top management, shareholders and competitors as stakeholders are scant, as illustrated by Figure 3.

This is alarming, given the role capital market stakeholders play in organizations vis-à-vis strategy formulation. Furthermore, the capital market stakeholder group itself can be the source of the talent, skills, capabilities and knowledge of multiple disciplines, as has been witnessed by charismatic top management and investors who are concerned about and support the natural environment.

The capital market stakeholder group needs to put in place the necessary steps for dynamic interactions amongst stakeholders, to have efficient and effective usage of resources and capabilities. For organizations to improve their capability to eco-innovate, the organization's capital market stakeholder group needs to configure their commitment to environmental issues and reassess their current capabilities. The capability of the organization to eco-innovate can then have an impact on other stakeholders through competitive advantage. Competitive advantage can in turn lead to superior performance. Hence, higher levels of commitment to the environment would be result in the capital market stakeholder group's eco-innovation strategy boosting its positive impact on other stakeholder groups—both internal and external. 


\subsection{Eco-innovation and Performance: Top Management Commitment}

Commitment to the environment by the top management has the potential to impact an organization's ability to eco-innovate. When eco-innovation is approached from the stakeholder theoretical lens, each stakeholder group has a dynamic two-way relationship with the organization. Top management is an internal stakeholder and a core influencer in the system of the organization through strategy formulation. As a key stakeholder, top management's commitment levels to the environment are critical, given their function in strategy formulation. In fact, amongst the stakeholder groups, top management may possess the most influence in driving the organization towards an eco-innovation strategy [109]. Whilst the top management is an integral part of the organization, and therefore a key stakeholder, other stakeholders are also important in other functional areas of the organization.

Thus, other stakeholder groups should continue to pay attention to the top management's commitment levels to the environment in order to ensure that they are able to formulate eco-innovation strategies that positively impact the organization, and consequently other stakeholder groups, such as shareholders, employees, customers and governments through its financial and environmental performance.

\subsection{Eco-innovation and Performance: Shareholders' Role}

This paper also identified that shareholders are a pivotal stakeholder group, as shareholding was also found to be a significant top management factor. This is due to shareholders being one of the key stakeholders of an organization. However, shareholders-who fall under the capital market stakeholder group-have received little coverage in eco-innovation and performance literature, as illustrated by Figures 3 and 4 earlier.

Hence, there is a shortfall in literature that analyzes the eco-innovation and performance relationship from the capital market stakeholder group (shareholders). Yet this stakeholder group is pivotal in both the decision making and performance of organizations. As providers of finance to the organization, shareholders are exposed to the highest risk-that is, their financial interests in the organization. Although developing new and radical technologies creates a risk for all stakeholders, the shareholders are the most exposed, as their value may be diminished or damaged in cases of unsuccessful innovations. In the case of eco-innovations and cleaner production technologies, they often require resources such as finance, and capabilities committed to them with an uncertain outcome. The uncertainty of eco-innovations may thus be of concern to shareholders and other providers of capital, that is, those financing the organization.

This stakeholder group is also closely related to all other stakeholders, but most importantly to the top management, as the top management is appointed by this group. Hence, top management's role as an agent and key stakeholder is to create value for the shareholders. Hence, it is important for top management to focus on the relationship of the organization to this important stakeholder group. Keeping shareholders satisfied is important for top management, who must then balance between satisfying shareholders and other stakeholder groups. Top management must also balance the risk that the eco-innovation strategy poses to its shareholders, versus the potential benefits and value creation to other key stakeholders of the organization.

Top management's incorporation of the environment in strategy could create additional value-keeping shareholders satisfied-if the top management's eco-innovation strategy is creating value for the capital market group. If the shareholders are also concerned about the environment, then it will be a more manageable task for top management to align the interests of all stakeholders. Galliano, Goncalves and Triboulet [107] support this notion by highlighting the importance of an organization's ownership in its eco-innovation practices. As important as the shareholders are to the organization, at this juncture however, it is worth noting the concerns raised earlier by Gelter [119] and Tyl, Vallet, Bocken and Real [33], who warned that dominance from this group could potentially be harmful for the interests of other stakeholders. For example, the motor vehicle industry was rocked by 
the emissions scandals [120] to the extent that some of the automakers have had to announce their intent of focusing on vehicles with hybrid or battery electric drive trains [121,122], saving shareholders from having their value further diminished.

\subsection{Eco-innovation and Performance: Industry Perspectives}

In addition, most of the investigations on the eco-innovation and performance relationship has extensively focused on the manufacturing industry, as earlier illustrated by Figure 4 This is not strange though, as most environmental regulations seem to be skewed towards ensuring the manufacturing industry lowers its negative environmental impact, a viewpoint shared by Pacheco et al. [123], Spedding [124] and Wang et al. [125].

Manufacturing has thus been extensively discussed from an eco-innovation and performance perspective. This is further buttressed by the fact that most organizations adopt or engage in eco-innovation practices towards their production operations.

For instance, Cheng et al. [126] found a strong relationship between eco-product and performance, as well as eco-process and performance, respectively. However, eco-innovation from the perspective of the service sector has received little coverage. This could be problematic, particularly as organizations are no longer solely focusing on providing products, but are also expected to be providing solutions, such as consultancy to customers of their products, so that the customers get the most out of their purchase [103]. Some organizations even package their market offering as an entire system, providing initial consultancy, set up, the product itself, and after sales service support/vendor support [127-129]. Hence, it is important to investigate the eco-innovation practices of companies that are moving towards servitization in the form of product-service system and service provisions.

\subsection{Eco-innovation and Performance: Geographical Context Dynamics}

Furthermore, most research on eco-innovation and performance has been concentrated on developed markets. This is an important fact, as different geographical and economic contexts have different effects on eco-innovation. This is because of different contexts exhibiting differences in terms of market dynamics, cleaner production technology availability, environmental regulation requirements, as well as different levels of enforcement [130]. For instance, Tsai and Liao [110] found that environmental regulation in their study context was light. Penalties for violation were light, incentives for compliance were low, and sentencing for environmental conviction was lenient. Meanwhile, Jabbour et al.'s [131] study reveals that the lack of regulatory incentives was a hinderance to eco-innovation in that particular context. Consequently, any motivation for compliance may be low in these contexts. However, when compared to the study of Dong et al. [132], the research context found that regulation increased the eco-innovation practices of organizations. Hence, investigating eco-innovation and performance from other geographical contexts would help in understanding the influence of that particular location's environmental regulations-which subsequently influence eco-innovation and performance.

\subsection{Eco-innovation and Performance: Theoretical and Managerial Implications}

This paper made several contributions to theory. Firstly, by analyzing eco-innovation and performance from the resource-based views and stakeholder theory, this paper contributed towards addressing the current limitations in eco-innovation research by identifying and analyzing eco-innovation factors from these theoretical perspectives. Most research that analyzes eco-innovation tends to utilize one distinct theory, such as a resource-based view. However, using more than one theory could help to overcome the potential weaknesses inherent in that theory. Therefore, eco-innovation and performance can be analyzed from a multi-dimension perspective to widen the scope of factors that can impact eco-innovation strategy in an organization - and subsequently performance.

Secondly, this literature review unearthed a few emerging areas such as top management environmental concern and shareholder environmental concern that have received little attention from 
a theoretical viewpoint. Thirdly, this paper proves that the resource-based views and stakeholder theory enjoy a dynamic relationship and are complementary to each other. The identified stakeholders that are important to these theories where top management and shareholders/ownership.

This paper showed that top management and shareholders are key stakeholders-as their environmental concern can greatly influence an organization's eco-innovation strategy orientation, which in turn impacts performance-subsequently impacting other stakeholders. External stakeholders can impact and be impacted by the top management, for example environmental pressure groups/lobbyists. However, although external stakeholders do impose pressure, it is top management who can have a positive bearing on eco-innovation and performance. The top management's commitment to eco-innovation can assist organizations in building up their abilities to infuse eco-innovation into their competencies and comply with environmental regulations whilst shareholders provide the necessary financial resources to enable eco-innovation.

\subsection{Eco-innovation and Performance: Future Research Avenues}

Given that innovations of any kind face a high degree of uncertainty, approaching eco-innovation strategy with more information and knowledge from multiple theoretical backgrounds could help mitigate this risk. One potential way of obtaining more information and knowledge to drive eco-innovation and performance is through the utilization of predictive analytics technology such as Big Data Analytics. Therefore, future reviews could explore eco-innovation and performance from an information and knowledge perspective, given the potential that data driven analytics capabilities have in driving eco-innovation and performance, and also the ability which Big Data Analytics have in reducing the high degree of uncertainty related to eco-innovations. Reducing uncertainties, and therefore risk, is important for stakeholders, particularly the shareholders who are most exposed to financial risk.

Secondly, eco-innovating successfully may also mean altering existing business models, or a completely radical, disruptive business model. For example, there could be eco-innovation in the form of new clean technologies, such as the emergence of new energy vehicle organizations with distinct eco-innovation capabilities. From the resource-based view, organizations must have the skills, capabilities and knowledge of multiple disciplines in order to increase the success of eco-innovations. Having the necessary resources is becoming increasingly important, even for established industry powerhouses, as they are ever more coming under threat from new players with a flair for eco-innovation. New players which have skills, capabilities and knowledge across a wide range of disciplines introduce disruptive cleaner eco-innovative products and technologies. Therefore, future research can possibly empirically investigate if organization characteristics such as age, size, sector, as well as the ownership structure, exhibits any differences in eco-innovation and performance.

Thirdly, it is not just organizational resources and capabilities that can be sources of competitive advantage. Interestingly, top management, as well as owners in of themselves, can potentially be sources of competitive advantage vis-à-vis their resource management and strategy formulation, as well as their knowledge, visions and leadership traits. The skills and capabilities of top management can then drive eco-innovation, ultimately resulting in a competitive advantage under the resource-based theories, and further enhancing value for stakeholders. Hence, when shareholders appoint or assess their agents (top management), having a look at the talent and skill sets of their agents is crucial, especially where the agent's skills and abilities complement their environmental concern. This fit or alignment of interests, skills and abilities can potentially be a great asset for organizations. In fact, such is the importance of top management in the competitive advantage strategy formulation and uncertainty reduction that many companies with innovation flair often "poach" talented top management from successful organizations. Hence, future research could empirically test organizations to see if top management characteristics such as education, age, domain experience, technical expertise and leadership style have any bearing on eco-innovation and performance. 
Lastly, organizations stand to benefit by assessing the challenges and opportunities afforded by the state of the natural environment. Therefore, tackling these environmental challenges requires organizations to be familiar with and garner the necessary experience to achieve eco-innovation. Hence, top management and shareholders, through their concern for the environment, could themselves become key drivers of eco-innovation-helping to create value for all stakeholders through sustainable development for a better tomorrow.

\section{Conclusions}

In this paper, organizational stakeholders, resources and capabilities were identified as important determinants of innovation and strategy. In an era of mounting environmental challenges, organizational resources, together with stakeholder synergies, need to be channeled towards addressing environmental challenges. This ability by organizations to innovatively tackle challenges to the natural environment can be the source of a sustainable competitive advantage. As a result, there is a growing importance of eco-innovations towards organizational competitiveness. Due to this growing importance, literature pertaining to eco-innovation and performance from a resource-based view and stakeholder theory was reviewed using a systematic method.

Firstly, the systematic review process allowed the research questions to be answered. Second, based upon the findings, gaps were identified. Contributions and pathways for future research were then recommended. Human capital, market demand, regulation and supply chain requirements were major contributors towards the eco-innovation and performance relationship. However, not enough attention has been paid to the capital market group of stakeholders. This is alarming, given the important role they play as capital providers to the organization.

The capital market stakeholder group can also influence the firm through several other means-such as selecting and appointing the executives/top management (principals) to formulate organizational strategy. The owners, as principals, wield significant power, especially when their ownership of shares is significantly large. However, it is also important that despite their importance, the views of ownership group should not be too dominant, as the interests of the other stakeholders must also be protected. In addition, the stakeholder theory-although a fundamental theory that explains organizational behavior beyond the interests of the shareholders-often is focused on human elements. However, it is not just human elements that could influence and provide ethical guidelines and heuristics for the organization. The natural environment, for instance, is overlooked by the stakeholder theory, yet the natural environment is a primary but non-human stakeholder whose interests must also be considered by the firm's decision makers.

Therefore, in order to overcome this limitation of the stakeholder theory when investigating the eco-innovation and performance relationship, this paper calls for the unique approach of complementing the stakeholder theory with the natural resource-based view (NRBV) for two main reasons. Firstly, the NRBV, by its nature, was introduced to compensate for the shortfall in the RBV. It compensates for the shortcoming of the RBV by incorporating the natural environment in the framework [13], which is important as markets and organizations are dependent upon the functionality of the natural environment. As natural environment challenges mount, firms that channel their resources and develop capabilities towards addressing environmental challenges will realize greater competitive advantage. For instance, firms that embed waste and GHG emission minimization by practicing continuous improvements of their products are able to develop the strategic capability of pollution prevention. This capability would help create lower production costs. In addition to the pollution prevention and product stewardship capabilities, firms ought to engage in cleaner production. Developing or using cleaner production technologies requires firms to have the capability of eco-innovation. Therefore, the NRBV is essential, as it simultaneously overcomes the limitations in both the stakeholder and RBV. Secondly, the stakeholder theory would add an interesting reinforcement to the eco-innovation and performance relationship, as it takes into account the ability of stakeholders to pressure the organization to remain competitive through 
eco-innovation. In fact, the stakeholder theory would be instrumental in considering organization specific attributes such as age, size and sector. These attributes are important as organizations that may be resource-disadvantaged due to these organizational attributes. Hence, such organizations may compensate for their resource-disadvantage through better management of stakeholder relationships. Better management of stakeholder relationships might therefore enable these resource-disadvantaged organizations to eco-innovate, and in turn improve performance [133]. Taking this strategic perspective would support organizations that strive to address the mounting environmental challenges while concurrently generating economic returns through a sustained competitive advantage- - key aspects of sustainable development.

This paper was not without limitations. Firstly, the literature reviewed in this paper originated from two databases only-the Scopus and Web of Science. Secondly, this paper focused on publications written in English. Third, this paper focused on empirical research and excluded book chapters and conference proceedings. Fourth, other synonyms of eco-innovation were not utilized in this paper.

Thus, future research could overcome these limitations by replicating this study and incorporating other scholarly databases such as Google Scholar. Another strategy to overcome limitations could be assembling a multi-language team of researchers.

Such a multi-language team will allow the limitations of one language to be overcome and will broaden the articles under review to more than one language. Furthermore, to increase the number of articles selected for analysis, book chapters, conference proceedings and other types of publications can be incorporated into future research. Lastly, using synonyms of eco-innovation could give future research an opportunity to understand the evolutionary nature of the subject matter.

Author Contributions: Conceptualization, R.T.M. and S.K.J.; methodology, R.T.M.; data curation, R.T.M.; validation, R.T.M. and S.K.J.; formal analysis, R.T.M.; investigation, R.T.M. and S.K.J.; resources, R.T.M.; writing-original draft preparation, R.T.M.; writing—-review and editing, R.T.M. and S.K.J.; visualization, R.T.M.; supervision, S.K.J.; project administration, S.K.J.; funding acquisition, R.T.M. and S.K.J.

Funding: This research was supported by the Yayasan UTP Fundamental Research Grant (YUTP-FRG), grant number 015LC0-016.

Acknowledgments: The authors would like to thank the Department of Management and Humanities, and the Centre for Graduate Studies for their support. The authors would also like to express gratitude to the four anonymous reviewers, whose comments and feedback helped to improve this paper.

Conflicts of Interest: The authors declare no conflict of interest. The funders had no role in the design of the study; in the collection, analyses, or interpretation of data; in the writing of the manuscript, or in the decision to publish the results.

\section{References}

1. Al-Ansari, T.; Korre, A.; Nie, Z.; Shah, N. Integration of greenhouse gas control technologies within the energy, water and food nexus to enhance the environmental performance of food production systems. J. Clean. Prod. 2017, 162, 1592-1606. [CrossRef]

2. Hajer, M.; Nilsson, M.; Raworth, K.; Bakker, P.; Berkhout, F.; De Boer, Y.; Rockström, J.; Ludwig, K.; Kok, M. Beyond Cockpit-ism: Four Insights to Enhance the Transformative Potential of the Sustainable Development Goals. Sustainability 2015, 7, 1651-1660. [CrossRef]

3. United Nations. Transforming Our World: The 2030 Agenda for Sustainable Development; United Nations: New York, NY, USA, 2015; pp. 1-35.

4. Dahle, K. Toward governance for future generations: How do we change course? Futures 1998, 30, $277-292$. [CrossRef]

5. Noble, I.; Scholes, R.J. Sinks and the Kyoto Protocol. Clim. Policy 2001, 1, 5-25. [CrossRef]

6. Ashby, M.F. Chapter 1-Background: Materials, Energy and Sustainability. In Materials and Sustainable Development; Ashby, M.F., Ed.; Butterworth-Heinemann: Boston, MA, USA, 2016; pp. 1-25.

7. Olawumi, T.O.; Chan, D.W.M. A scientometric review of global research on sustainability and sustainable development. J. Clean. Prod. 2018, 183, 231-250. [CrossRef] 
8. Ricci, E.C.; Banterle, A.; Stranieri, S. Trust to Go Green: An Exploration of Consumer Intentions for Eco-friendly Convenience Food. Ecol. Econ. 2018, 148, 54-65. [CrossRef]

9. Wang, Y.; Shen, N. Environmental regulation and environmental productivity: The case of China. Renew. Sustain. Energy Rev. 2016, 62, 758-766. [CrossRef]

10. Stock, T.; Obenaus, M.; Kunz, S.; Kohl, H. Industry 4.0 as enabler for a sustainable development: A qualitative assessment of its ecological and social potential. Process. Saf. Environ. Prot. 2018, 118, 254-267. [CrossRef]

11. Ball, P.; Lunt, P. Lean eco-efficient innovation in operations through the maintenance organisation. Int. J. Prod. Econ. 2018. [CrossRef]

12. Pham, D.D.T.; Paillé, P.; Halilem, N. Systematic review on environmental innovativeness: A knowledge-based resource view. J. Clean. Prod. 2019, 211, 1088-1099. [CrossRef]

13. Hart, S.L. A Natural-Resource-Based View of the Firm. Acad. Manag. Rev. 1995, 20, 986-1014. [CrossRef]

14. Rennings, K. Redefining innovation-Eco-innovation research and the contribution from ecological economics. Ecol. Econ. 2000, 32, 319-332. [CrossRef]

15. Donaldson, T.; Preston, L.E. The Stakeholder Theory of the Corporation: Concepts, Evidence, and Implications. Acad. Manag. Rev. 1995, 20, 65-91. [CrossRef]

16. Carrillo-Hermosilla, J.; del González, P.R.; Könnölä, T. What is eco-innovation? In Eco-Innovation: When Sustainability and Competitiveness Shake Hands; Palgrave Macmillan UK: London, UK, 2009; pp. 6-27.

17. Prieto-Sandoval, V.; Jaca, C.; Ormazabal, M. Towards a consensus on the circular economy. J. Clean. Prod. 2018, 179, 605-615. [CrossRef]

18. De Jesus, A.; Antunes, P.; Santos, R.; Mendonça, S. Eco-innovation in the transition to a circular economy: An analytical literature review. J. Clean. Prod. 2018, 172, 2999-3018. [CrossRef]

19. Von Geibler, J.; Bienge, K.; Schüwer, D.; Berthold, O.; Dauensteiner, A.; Grinewitschus, V.; Hoffmann, D.; Renner, W.; Ostermeyer, Y. Identifying business opportunities for green innovations: A quantitative foundation for accelerated micro-fuel cell diffusion in residential buildings. Energy Rep. 2018, 4, 226-242. [CrossRef]

20. Sjöström, J.; Talanquer, V. Eco-reflexive chemical thinking and action. Curr. Opin. Green Sustain. Chem. 2018, 13, 16-20. [CrossRef]

21. Gude, V.G. Sustainable chemistry and chemical processes for a sustainable future. Resour. Effic. Technol. 2017, 3, 249-251. [CrossRef]

22. Dewick, P.; Foster, C. Focal Organisations and Eco-innovation in Consumption and Production Systems. Ecol. Econ. 2018, 143, 161-169. [CrossRef]

23. World Economic Forum. The Role of Technology Innovation in Accelerating Food Systems Transformation; World Economic Forum: Geneva, Switzerland, 2018.

24. Prendeville, S.; O'Connor, F.; Palmer, L. Material selection for eco-innovation: SPICE model. J. Clean. Prod. 2014, 85, 31-40. [CrossRef]

25. Löbberding, L.; Madlener, R. System Cost Uncertainty of Micro Fuel Cell Cogeneration and Storage. Energy Procedia 2017, 142, 2824-2830. [CrossRef]

26. He, F.; Miao, X.; Wong, C.W.Y.; Lee, S. Contemporary corporate eco-innovation research: A systematic review. J. Clean. Prod. 2018, 174, 502-526. [CrossRef]

27. Anzola-Román, P.; Bayona-Sáez, C.; García-Marco, T. Organizational innovation, internal R\&D and externally sourced innovation practices: Effects on technological innovation outcomes. J. Bus. Res. 2018, 91, 233-247.

28. Ruiz-Jiménez, J.M.; del Mar Fuentes-Fuentes, M. Management capabilities, innovation, and gender diversity in the top management team: An empirical analysis in technology-based SMEs. BRQ Bus. Res. Q. 2016, 19, 107-121. [CrossRef]

29. Kotsemir, M.; Abroskin, A.; Meissner, D. Innovation Concepts and Typology-An Evolutionary Discussion. High. Sch. Econ. 2013. [CrossRef]

30. Del Río, P.; Carrillo-Hermosilla, J.; Könnölä, T.; Bleda, M. Resources, capabilities and competences for eco-innovation. Technol. Econ. Dev. Econ. 2016, 22, 274-292. [CrossRef]

31. Bossle, M.B.; Dutra de Barcellos, M.; Vieira, L.M.; Sauvée, L. The drivers for adoption of eco-innovation. J. Clean. Prod. 2016, 113, 861-872. [CrossRef]

32. Xavier, A.F.; Naveiro, R.M.; Aoussat, A.; Reyes, T. Systematic literature review of eco-innovation models: Opportunities and recommendations for future research. J. Clean. Prod. 2017, 149, 1278-1302. [CrossRef] 
33. Tyl, B.; Vallet, F.; Bocken, N.M.P.; Real, M. The integration of a stakeholder perspective into the front end of eco-innovation: A practical approach. J. Clean. Prod. 2015, 108, 543-557. [CrossRef]

34. Del Río, P.; Peñasco, C.; Romero-Jordán, D. What drives eco-innovators? A critical review of the empirical literature based on econometric methods. J. Clean. Prod. 2016, 112, 2158-2170. [CrossRef]

35. Salim, N.; Ab Rahman, M.N.; Abd Wahab, D. A systematic literature review of internal capabilities for enhancing eco-innovation performance of manufacturing firms. J. Clean. Prod. 2019, 209, 1445-1460. [CrossRef]

36. Hazarika, N.; Zhang, X. Evolving theories of eco-innovation: A systematic review. Sustain. Prod. Consum. 2019, 19, 64-78. [CrossRef]

37. Schumpeter, J.A.; Opie, R.; Elliott, J.E. The Theory of Economic Development: An Inquiry into Profits, Capital, Credit, Interest, and the Business Cycle; Routledge: New York, NY, USA, 2017.

38. Von Krogh, G.; Ichijo, K.; Nonaka, I. Enabling Knowledge Creation: How to Unlock the Mystery of Tacit Knowledge and Release the Power of Innovation; Oxford University Press: Oxford, UK, 2011; pp. 1-302.

39. Välikangas, L. Manage innovation as a corporate capability. Chem. Eng. Prog. 2003, 99, 64-69.

40. Vanhaverbeke, W.; Peeters, N. Embracing Innovation as Strategy: Corporate Venturing, Competence Building and Corporate Strategy Making. Creat. Innov. Manag. 2005, 14, 246-257. [CrossRef]

41. Kodama, M. Developing strategic innovation in large corporations-The dynamic capability view of the firm. Knowl. Process. Manag. 2017, 24, 221-246. [CrossRef]

42. Breznik, L.; Lahovnik, M. Innovation capability as a source of competitive advantage in Slovenian information technology firms. Tech. Technol. Educ. Manag. 2012, 7, 1132-1143.

43. Pavitt, K. Sectoral patterns of technical change: Towards a taxonomy and a theory. Res. Policy 1984, 13, 343-373. [CrossRef]

44. Geels, F.W. From sectoral systems of innovation to socio-technical systems: Insights about dynamics and change from sociology and institutional theory. Res. Policy 2004, 33, 897-920. [CrossRef]

45. Choi, T.Y.; Krause, D.R. The supply base and its complexity: Implications for transaction costs, risks, responsiveness, and innovation. J. Oper. Manag. 2006, 24, 637-652. [CrossRef]

46. Eiriz, V.; Faria, A.; Barbosa, N. Firm growth and innovation: Towards a typology of innovation strategy. Innov. Manage. Policy Pract. 2013, 15, 97-111. [CrossRef]

47. Zhang, L.; Zhou, R.; Xu, J. An exploratory case study of the relationship between strategy and brand value based on innovation choice. In Proceedings of the 9th International Conference on Management Science and Engineering Management (ICMSEM 2015), Karlsruhe, Germany, 21-23 July 2015; Machado, V.C., Xu, J., Nickel, S., Hajiyev, A., Eds.; Springer Verlag: Berlin/Heidelberg, Germany, 2015; pp. 1055-1063.

48. Persaud, A. Enhancing synergistic innovative capability in multinational corporations: An empirical investigation. J. Prod. Innov. Manag. 2005, 22, 412-429. [CrossRef]

49. Wang, C.L.; Ahmed, P.K. The development and validation of the organisational innovativeness construct using confirmatory factor analysis. Eur. J. Innov. Manag. 2004, 7, 303-313. [CrossRef]

50. Vicente, M.; Abrantes, J.L.; Teixeira, M.S. Measuring innovation capability in exporting firms: The INNOVSCALE. Int. Mark. Rev. 2015, 32, 29-51. [CrossRef]

51. Lefebvre, E.; Lefebvre, L.A.; Talbot, S. Environmental Initiatives, Innovativeness and Competitiveness: Some Empirical Evidence. In Proceedings of the 2000 IEEE Engineering Management Society. EMS—2000 (Cat. No.00CH37139), Albuquerque, NM, USA, 15 August 2000; pp. 674-679.

52. Singh, P.J.; Mittal, V.K.; Sangwan, K.S. Development and validation of performance measures for environmentally conscious manufacturing. Int. J. Serv. Oper. Manag. 2013, 14, 197-220. [CrossRef]

53. Mousavi, S.; Bossink, B.; van Vliet, M. Dynamic capabilities and organizational routines for managing innovation towards sustainability. J. Clean. Prod. 2018, 203, 224-239. [CrossRef]

54. Sakalayen, Q.M.H.; Chen, P.S.L.; Cahoon, S. Investigating the strategies for Australian regional ports' involvement in regional development. Int. J. Shipp. Transp. Logist. 2016, 8, 153-174. [CrossRef]

55. Vickers, I. Cleaner production: Organizational learning or business as usual? An example from the domestic appliance industry. Bus. Strategy Environ. 2000, 9, 255-268. [CrossRef]

56. Khanna, M.; Kumar, S. Corporate Environmental Management and Environmental Efficiency. Environ. Resour. Econ. 2011, 50, 227-242. [CrossRef]

57. Walls, J.L.; Phan, P.H.; Berrone, P. Measuring environmental strategy: Construct development, reliability, and validity. Bus. Soc. 2011, 50, 71-115. [CrossRef] 
58. Green, K.; McMeekin, A.; Irwin, A. Technological trajectories and R\&D for environmental innovation in UK firms. Futures 1994, 26, 1047-1059.

59. Kemp, R.; Pearson, P. Final Report MEI Project about Measuring Eco-Innovation; European Commission: Brussels, Belgium, 2007.

60. Organisation for Economic Co-operation and Development (OECD). Oslo Manual; European Commission, Eurostat: Luxembourg, 2005.

61. Skeete, J.P. Examining the role of policy design and policy interaction in EU automotive emissions performance gaps. Energy Policy 2017, 104, 373-381. [CrossRef]

62. Carrillo-Hermosilla, J.; Del Río, P.; Könnölä, T. Diversity of eco-innovations: Reflections from selected case studies. J. Clean. Prod. 2010, 18, 1073-1083. [CrossRef]

63. Coenen, L.; Díaz López, F.J. Comparing systems approaches to innovation and technological change for sustainable and competitive economies: An explorative study into conceptual commonalities, differences and complementarities. J. Clean. Prod. 2010, 18, 1149-1160. [CrossRef]

64. González-García, S.; García Lozano, R.; Buyo, P.; Pascual, R.C.; Gabarrell, X.; Rieradevall, I.; Pons, J.; Moreira, M.T.; Feijoo, G. Eco-innovation of a wooden based modular social playground: Application of LCA and DfE methodologies. J. Clean. Prod. 2012, 27, 21-31. [CrossRef]

65. Huang-Lachmann, J.T.; Lovett, J.C. How cities prepare for climate change: Comparing Hamburg and Rotterdam. Cities 2016, 54, 36-44. [CrossRef]

66. Nag, S.; Mondal, A.; Bar, N.; Das, S.K. Biosorption of chromium (VI) from aqueous solutions and ANN modelling. Environ. Sci. Pollut. Res. 2017, 24, 18817-18835. [CrossRef] [PubMed]

67. López, F.J.D.; Montalvo, C. A comprehensive review of the evolving and cumulative nature of eco-innovation in the chemical industry. J. Clean. Prod. 2015, 102, 30-43. [CrossRef]

68. Bag, S.; Gupta, S. Antecedents of Sustainable Innovation in Supplier Networks: A South African Experience. Glob. J. Flex. Syst. Manag. 2017, 18, 231-250. [CrossRef]

69. Wheelen, T.L.; Hunger, J.D.; Hoffman, A.N.; Bamford, C.E. Strategic Management and Business Policy: Globalization, Innovation and Sustainability; Pearson Education: London, UK, 2014.

70. Wernerfelt, B. A resource-based view of the firm. Strateg. Manag. J. 1984, 5, 171-180. [CrossRef]

71. Hall, R. A framework linking intangible resources and capabiliites to sustainable competitive advantage. Strateg. Manag. J. 1993, 14, 607-618. [CrossRef]

72. Kiefer, C.P.; Carrillo-Hermosilla, J.; Del Río, P.; Callealta Barroso, F.J. Diversity of eco-innovations: A quantitative approach. J. Clean. Prod. 2017, 166 (Suppl. C), 1494-1506. [CrossRef]

73. Backman, C.A.; Verbeke, A.; Schulz, R.A. The Drivers of Corporate Climate Change Strategies and Public Policy: A New Resource-Based View Perspective. Bus. Soc. 2017, 56, 545-575. [CrossRef]

74. Barney, J.B. Is the Resource-Based "View" a Useful Perspective for Strategic Management Research? Yes. Acad. Manag. Rev. 2001, 26, 41-56.

75. Barney, J.B. Firm Resources and Sustained Competitive Advantage. J. Manag. 1991, 17, 99-120. [CrossRef]

76. Chatzoglou, P.; Chatzoudes, D.; Sarigiannidis, L.; Theriou, G. The role of firm-specific factors in the strategy-performance relationship: Revisiting the resource-based view of the firm and the VRIO framework. Manag. Res. Rev. 2018, 41, 46-73. [CrossRef]

77. Bobillo, A.M.; Rodríguez-Sanz, J.A.; Tejerina-Gaite, F. Corporate governance drivers of firm innovation capacity. Rev. Int. Econ. 2018, 26, 721-741. [CrossRef]

78. Yadav, P.L.; Han, S.H.; Kim, H. Sustaining Competitive Advantage Through Corporate Environmental Performance. Bus. Strategy Environ. 2017, 26, 345-357. [CrossRef]

79. Kitchenham, B.A. Systematic reviews. In Proceedings of the 10th International Symposium on Software Metrics (METRICS 2004), Chicago, IL, USA, 11-17 September 2004.

80. Fisch, C.; Block, J. Six tips for your (systematic) literature review in business and management research. Manag. Rev. Q. 2018, 68, 103-106. [CrossRef]

81. Tranfield, D.; Denyer, D.; Smart, P. Towards a Methodology for Developing Evidence-Informed Management Knowledge by Means of Systematic Review. Br. J. Manag. 2003, 14, 207-222. [CrossRef]

82. Karakaya, E.; Hidalgo, A.; Nuur, C. Diffusion of eco-innovations: A review. Renew. Sustain. Energy Rev. 2014, 33, 392-399. [CrossRef]

83. González-Moreno, Á.; Sáez-Martínez, F.J. Eco-innovation: Insights from a literature review AU—Díaz-García, Cristina. Innovation 2015, 17, 6-23. 
84. Powell, K.R.; Peterson, S.R. Coverage and quality: A comparison of Web of Science and Scopus databases for reporting faculty nursing publication metrics. Nurs. Outlook 2017, 65, 572-578. [CrossRef] [PubMed]

85. Morioka, S.N.; de Carvalho, M.M. A systematic literature review towards a conceptual framework for integrating sustainability performance into business. J. Clean. Prod. 2016, 136, 134-146. [CrossRef]

86. Teixeira da Silva, J.A.; Memon, A.R. CiteScore: A cite for sore eyes, or a valuable, transparent metric? Scientometrics 2017, 111, 553-556. [CrossRef]

87. Peteraf, M.A. The cornerstones of competitive advantage: A resource-based view. Strateg. Manag. J. 1993, 14, 179-191. [CrossRef]

88. Freeman, R.E. Strategic Management: A Stakeholder Approach; Cambridge University Press: Cambridge, UK, 2015; pp. 1-276.

89. Waddock, S.A.; Bodwell, C.; Graves, S.B. Responsibility: The new business imperative. Acad. Manag. Exec. 2002, 16, 132-148. [CrossRef]

90. Hitt, M.A.; Ireland, R.D.; Hoskisson, R.E. Strategic Management: Competitiveness $\mathcal{E}$ Globalization: Concepts, 12th ed.; Cengage Learning: Boston, MA, USA, 2016.

91. Díaz-Fernández, M.C.; González-Rodríguez, M.R.; Simonetti, B. Top management team's intellectual capital and firm performance. Eur. Manag. J. 2015, 33, 322-331. [CrossRef]

92. Hyväri, I. Roles of Top Management and Organizational Project Management in the Effective Company Strategy Implementation. Procedia Soc. Behav. Sci. 2016, 226, 108-115. [CrossRef]

93. Dobni, C.B.; Sand, C. Strategy shift: Integrating strategy and the firm's capability to innovate. Bus. Horiz. 2018, 61, 797-808. [CrossRef]

94. Knight, G.A.; Cavusgil, S.T. Innovation, organizational capabilities, and the born-global firm. J. Int. Bus. Stud. 2004, 35, 124-141. [CrossRef]

95. Fernando, Y.; Wah, W.X.; Shaharudin, M.S. Does a firm's innovation category matter in practising eco-innovation? Evidence from the lens of Malaysia companies practicing green technology. J. Manuf. Technol. Manag. 2016, 27, 208-233. [CrossRef]

96. Muscio, A.; Nardone, G.; Stasi, A. How does the search for knowledge drive firms' eco-innovation? Evidence from the wine industry. Ind. Innov. 2017, 24, 298-320. [CrossRef]

97. Horbach, J.; Rammer, C.; Rennings, K. Determinants of eco-innovations by type of environmental impact-The role of regulatory push/pull, technology push and market pull. Ecol. Econ. 2012, 78, 112-122. [CrossRef]

98. Sanni, M. Drivers of eco-innovation in the manufacturing sector of Nigeria. Technol. Forecast. Soc. Chang. 2018, 131, 303-314. [CrossRef]

99. Wu, K.J.; Liao, C.J.; Chen, C.C.; Lin, Y.H.; Tsai, C.F.M. Exploring eco-innovation in dynamic organizational capability under incomplete information in the Taiwanese lighting industry. Int. J. Prod. Econ. 2016, 181, 419-440. [CrossRef]

100. Ma, D.; Ye, J.M.; Zhang, Y.R. Can Firm Exploit Economic Gainsfrom Eco-Innovation? An Empirical Investigation of Listed Companiesin China. Transform. Bus. Econ. 2018, 17, 33-53.

101. Portillo-Tarragona, P.; Scarpellini, S.; Moneva, J.M.; Valero-Gil, J.; Aranda-Usón, A. Classification and measurement of the firms' resources and capabilities applied to eco-innovation projects from a resource-based view perspective. Sustainability 2018, 10, 3161. [CrossRef]

102. Tsai, K.H.; Liao, Y.C. Sustainability Strategy and Eco-Innovation: A Moderation Model. Bus. Strategy Environ. 2017, 26, 426-437. [CrossRef]

103. Fernando, Y.; Wah, W.X. The impact of eco-innovation drivers on environmental performance: Empirical results from the green technology sector in Malaysia. Sustain. Prod. Consum. 2017, 12, 27-43. [CrossRef]

104. Ganapathy, S.P.; Natarajan, J.; Gunasekaran, A.; Subramanian, N. Influence of eco-innovation on Indian manufacturing sector sustainable performance. Int. J. Sustain. Dev. World Ecol. 2014, 21, 198-209. [CrossRef]

105. Park, M.S.; Bleischwitz, R.; Han, K.J.; Jang, E.K.; Joo, J.H. Eco-innovation indices as tools for measuring eco-innovation. Sustainability 2017, 9, 2206. [CrossRef]

106. Blum-Kusterer, M.; Hussain, S.S. Innovation and corporate sustainability: An investigation into the process of change in the pharmaceuticals industry. Bus. Strategy Environ. 2001, 10, 300-316. [CrossRef]

107. Galliano, D.; Goncalves, A.; Triboulet, P. Eco-Innovations in Rural Territories: Organizational Dynamics and Resource Mobilization in Low Density Areas. J. Innov. Econ. Manag. 2017, 3, 35-62. [CrossRef]

108. Ratten, V. Eco-innovation and competitiveness in the Barossa Valley wine region. Compet. Rev. 2018, 28, 318-331. [CrossRef] 
109. Bossle, M.B.; De Barcellos, M.D.; Vieira, L.M. Why food companies go green? The determinant factors to adopt eco-innovations. Br. Food J. 2016, 118, 1317-1333. [CrossRef]

110. Tsai, K.H.; Liao, Y.C. Innovation Capacity and the Implementation of Eco-innovation: Toward a Contingency Perspective. Bus. Strategy Environ. 2017, 26, 1000-1013. [CrossRef]

111. Zhang, J.A.; Walton, S. Eco-innovation and business performance: The moderating effects of environmental orientation and resource commitment in green-oriented SMEs. R D Manag. 2017, 47, E26-E39. [CrossRef]

112. Severo, E.A.; de Guimaraes, J.C.F.; Dorion, E.C.H. Cleaner production, social responsibility and eco-innovation: Generations' perception for a sustainable future. J. Clean. Prod. 2018, 186, 91-103. [CrossRef]

113. Liao, Y.C.; Tsai, K.H. Innovation intensity, creativity enhancement, and eco-innovation strategy: The roles of customer demand and environmental regulation. Bus. Strategy Environ. 2018, 28, 316-326. [CrossRef]

114. Ryszko, A. Proactive Environmental Strategy, Technological Eco-Innovation and Firm Performance-Case of Poland. Sustainability 2016, 8, 156. [CrossRef]

115. Alhyasat, W.M.K.; Sharif, Z.M.; Alhyasat, K.M. The mediating effect of eco-innovation between motivation and organization performance in Jordan Industrial Estates Company in Jordan. Int. J. Eng. Technol. 2018, 7, 414-423. [CrossRef]

116. Aboelmaged, M. Direct and indirect effects of eco-innovation, environmental orientation and supplier collaboration on hotel performance: An empirical study. J. Clean. Prod. 2018, 184, 537-549. [CrossRef]

117. Marín-Vinuesa, L.M.; Scarpellini, S.; Portillo-Tarragona, P.; Moneva, J.M. The Impact of Eco-Innovation on Performance Through the Measurement of Financial Resources and Green Patents. Organ. Environ. 2018. [CrossRef]

118. Scarpellini, S.; Marín-Vinuesa, L.M.; Portillo-Tarragona, P.; Moneva, J.M. Defining and measuring different dimensions of financial resources for business eco-innovation and the influence of the firms' capabilities. J. Clean. Prod. 2018, 204, 258-269. [CrossRef]

119. Gelter, M. The dark side of shareholder influence: Managerial autonomy and stakeholder orientation in comparative corporate governance. Harv. Int. Law J. 2009, 50, 129-194.

120. Li, L.; McMurray, A.; Xue, J.; Liu, Z.; Sy, M. Industry-wide corporate fraud: The truth behind the Volkswagen scandal. J. Clean. Prod. 2018, 172, 3167-3175. [CrossRef]

121. Sushandoyo, D.; Magnusson, T. Strategic niche management from a business perspective: Taking cleaner vehicle technologies from prototype to series production. J. Clean. Prod. 2014, 74, 17-26. [CrossRef]

122. Borthakur, S.; Subramanian, S.C. Optimized Design and Analysis of a Series-Parallel Hybrid Electric Vehicle Powertrain for a Heavy Duty Truck. IFAC PapersOnLine 2018, 51, 184-189. [CrossRef]

123. De Jesus Pacheco, D.A.; ten Caten, C.S.; Jung, C.F.; Ribeiro, J.L.D.; Navas, H.V.G.; Cruz-Machado, V.A. Eco-innovation determinants in manufacturing SMEs: Systematic review and research directions. J. Clean. Prod. 2017, 142, 2277-2287. [CrossRef]

124. Spedding, L.S. Chapter 16-Environmental due diligence and risk management: Sustainability and corporate governance. In Due Diligence Handbook; Spedding, L.S., Ed.; CIMA Publishing: Oxford, UK, 2009; pp. 535-641.

125. Wang, Y.; Liu, J.; Hansson, L.; Zhang, K.; Wang, R. Implementing stricter environmental regulation to enhance eco-efficiency and sustainability: A case study of Shandong Province's pulp and paper industry, China. J. Clean. Prod. 2011, 19, 303-310. [CrossRef]

126. Cheng, C.C.J.; Yang, C.L.; Sheu, C. The link between eco-innovation and business performance: A Taiwanese industry context. J. Clean. Prod. 2014, 64, 81-90. [CrossRef]

127. Laperche, B.; Picard, F. Environmental constraints, Product-Service Systems development and impacts on innovation management: Learning from manufacturing firms in the French context. J. Clean. Prod. 2013, 53, 118-128. [CrossRef]

128. Wasserbaur, R.; Sakao, T. Analysing interplays between PSS business models and governmental policies towards a circular economy. Procedia CIRP 2018, 73, 130-136. [CrossRef]

129. Wang, Y.-Y.; Wang, Y.-S.; Lin, T.-C. Developing and validating a technology upgrade model. Int. J. Inf. Manag. 2018, 38, 7-26. [CrossRef]

130. Lee, K.H.; Min, B. Green R\&D for eco-innovation and its impact on carbon emissions and firm performance. J. Clean. Prod. 2015, 108, 534-542.

131. Jabbour, C.J.C.; Jugend, D.; de Sousa Jabbour, A.B.L.; Govindan, K.; Kannan, D.; Leal Filho, W. “There is no carnival without samba": Revealing barriers hampering biodiversity-based R\&D and eco-design in Brazil. J. Environ. Manag. 2018, 206, 236-245. 
132. Dong, Y.; Wang, X.; Jin, J.; Qiao, Y.; Shi, L. Effects of eco-innovation typology on its performance: Empirical evidence from Chinese enterprises. J. Eng. Technol. Manag. 2014, 34, 78-98. [CrossRef]

133. Andries, P.; Stephan, U. Environmental Innovation and Firm Performance: How Firm Size and Motives Matter. Sustainability 2019, 11, 3585. [CrossRef]

(C) 2019 by the authors. Licensee MDPI, Basel, Switzerland. This article is an open access article distributed under the terms and conditions of the Creative Commons Attribution (CC BY) license (http://creativecommons.org/licenses/by/4.0/). 